\title{
Diversity of marine gliding bacteria in Thailand and their cytotoxicity
}

\author{
Yutthapong Sangnoi \\ Department of Industrial Biotechnology \\ Faculty of Agro-Industry \\ Prince of Songkla University \\ Hat Yai, Songkhla 90112, Thailand \\ Pornpoj Srisukchayakul \\ Thailand Institute of Scientific and Technological Research \\ 35 Moo 3, Technopolis, Khlong 5, Khlong Luang \\ Pathum Thani 12120, Thailand \\ Vullapa Arunpairojana \\ Thailand Institute of Scientific and Technological Research \\ 35 Moo 3, Technopolis, Khlong 5, Khlong Luang \\ Pathum Thani 12120, Thailand

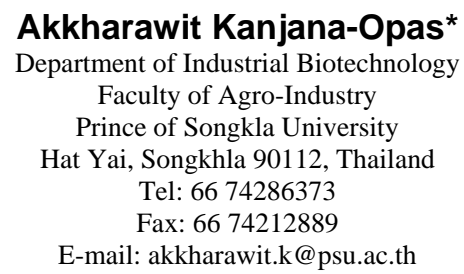

Financial support: Thailand Research Fund (MRG4880153) and a Biodiversity Research and Training Grant (BRTR_149011). Scholarship for YS from the Graduate School, Prince of Songkla University.

Keywords: Aureispira marina, Aureispira maritime, Fulvivirga kasyanovii, human cell lines, Rapidithrix thailandica, Tenacibaculum mesophilum.

\author{
Abbreviations: CFB: Cytophaga-Flavobacterium-Bacteriodes \\ HeLa: cervical cancer \\ HT-29: colon cancer \\ KB: oral cancer \\ MCF-7: breast adenocarcinoma \\ PCR: polymerase chain reaction \\ SK: skim milk medium \\ SRB: sulphorodamine B
}

Eighty-four marine gliding bacteria were isolated from specimens collected in the Gulf of Thailand and the Andaman Sea. All exhibited gliding motility and swarm colonies on cultivation plates and they were purified by subculturing and micromanipulator techniques. Their 16S rRNA genes were amplified by the polymerase chain reaction (PCR) technique. The phylogenetic analysis indicated that the represented isolates can be separated into six different clads (gr 1 - gr 6) within the Cytophaga-Flavobacterium-Bacteriodes (CFB) group. Group 1 formed a remote linear, with only $90 \%$ sequence similarity, from Flavobacteriaceae bacterium which indicated a potentially novel taxonomic group. Groups 2 and 3 were identified as the recently proposed Tenacibaculum mesophilum and Fulvivirga kasyanovii respectively. Groups 4, 5 and 6, consisting of the largest number of the members, were identified as Rapidithrix thailandica, Aureispira marina and Aureispira maritima respectively. The isolates were cultivated in four different cultivation media (Vy/2, RL 1, CY and SK) and the crude extracts were submitted to screen cytotoxicity using a sulphorodamine B (SRB) assay. The results from cytotoxic screening showed that groups 2, 4 and 6 were capable of producing the cytotoxic metabolites against selected human cell lines (breast adenocarcinoma (MCF-7), colon cancer (HT-29), cervical cancer (HeLa) and oral cancer (KB)). However, groups 1,3 and 5 did not produce metabolites with cytotoxicity when cultivated in the same cultivation media as the previous groups. CY medium was the only cultivation medium which could yield the cytotoxic metabolites against MCF-7.

Research to discover anticancer drugs have been the major

*Corresponding author 


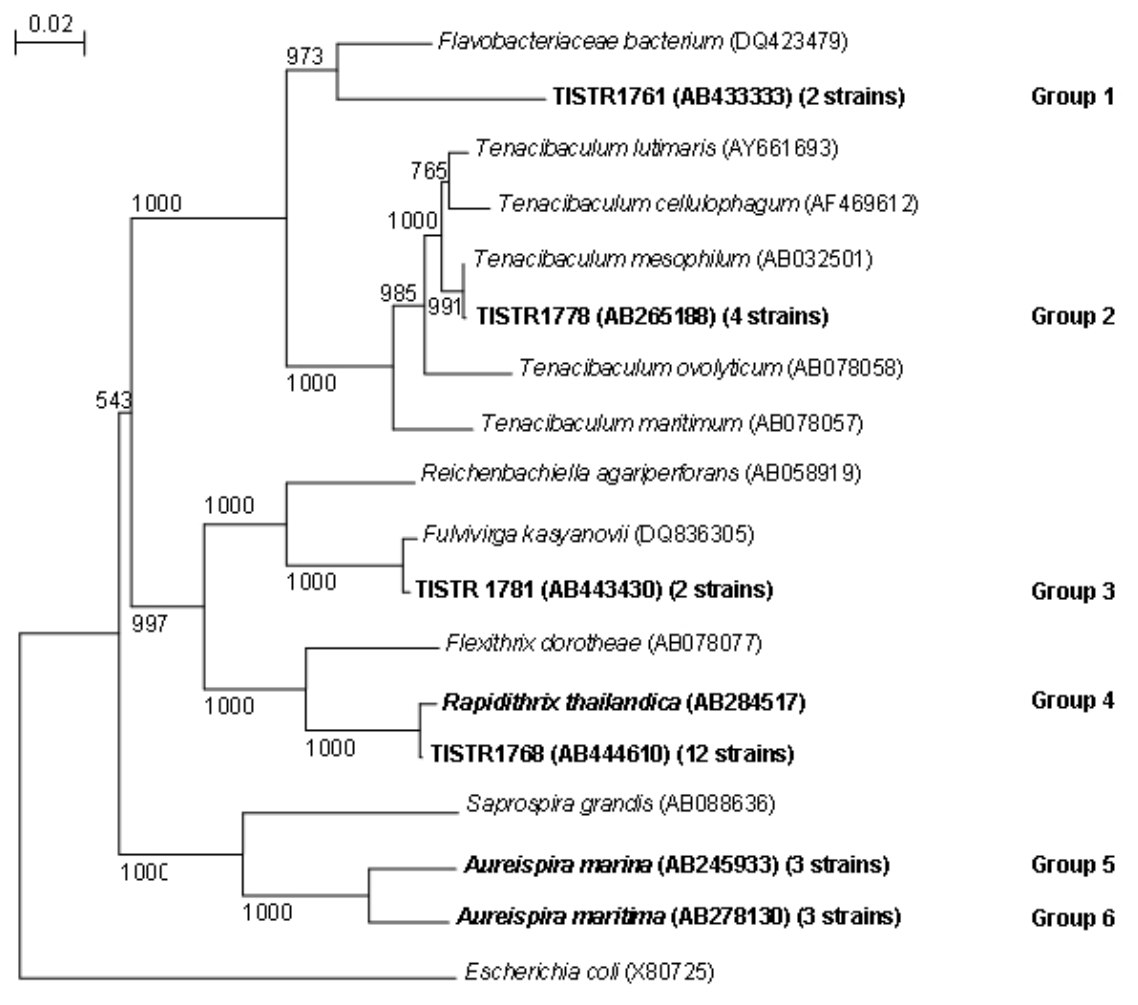

Figure 1. Neighbor-joining tree showing the positions of marine gliding bacterial isolates and related members of the CFB group based on 16S rRNA gene sequence analysis. Bootstrap values of more than 500 are given at branch points. Bar $=0.02$

focus of natural product researchers worldwide. This is due to the increasing number of cancer patients, the lack of selectivity of most anticancer agents (Miot-Noirault et al. 2004), the development of resistance to drugs (Hutson et al. 2004) and the serious adverse side effects of currently available anticancer drugs (Schilder et al. 2004). Therefore, the need for new cancer drugs is very crucial.

In the past thirty years, several researchers have demonstrated that marine organisms, especially marine invertebrates are capable of producing cytotoxic compounds (Izbicka et al. 1998; Boyd et al. 2001; Curiel et al. 2001). However, marine microorganisms are understudied and only a few cytotoxic compounds have been reported so far. The examples are palau'amide (Williams et al. 2003), salinosporamide A (Feling et al. 2003), micromide (Williams et al. 2004), resistoflavine (Gorajana et al. 2007), and trichodermamide B (Garo et al. 2003). Interestingly, cytotoxic compounds from marine microorganisms have been produced mainly by marine fungi and actinomycetes.

Gliding bacteria are the group of Gram negative bacteria with unique gliding motility and distributed in various habitats (Johansen et al. 1999; Barbeyron et al. 2001; Nakagawa et al. 2001; Hosoya et al. 2006; Hosoya et al. 2007; Srisukchayakul et al. 2007). Despite the increasing number of reports on isolation of novel marine gliding bacteria, little is known about their secondary metabolites and their potential uses as sources of bioactive compounds. So far only few metabolites, haliangicin (Fudou et al. 2001), neoverrucosane diterpenoids (Spyere et al. 2003), miuraenamides (Iizuka et al. 2006) and marinoquinoline A (Kanjana-Opas et al. 2006), have been reported from marine gliding bacteria indicating they are untapped resources awaiting exploitation. Thailand is located in the high biodiversities zone having uniquely different marine habitats both in the Indian Ocean (Andaman Sea) and the Pacific Ocean (Gulf of Thailand). Although the biodiversity of marine gliding bacteria are understudied in Thailand and elsewhere, our reports on discovery of marine gliding bacteria in Thailand in the past decade have shown the promising results (Hosoya et al. 2006; Hosoya et al. 2007; Srisukchayakul et al. 2007).

In this paper we aim to report the isolation, identification, and classification of novel groups of marine gliding bacteria from Thailand and their potential as sources of cytotoxic compounds.

\section{MATERIALS AND METHODS}

\section{Isolation and purification}

In this study, a modified seawater glutamate medium (SWG) containing $L$-Glutamic acid monosodium salt, $1.0 \mathrm{~g}$; $\mathrm{NH}_{4} \mathrm{NO}_{3}, 0.01 \mathrm{~g} ; \mathrm{K}_{2} \mathrm{HPO}_{4}, 0.01 \mathrm{~g}$; agar $15 \mathrm{~g}$ and seawater, $1 \mathrm{~L}$ (Hosoya et al. 2006) was used for the isolation of marine gliding bacteria from marine specimens such as 
Diversity of marine gliding bacteria in Thailand and their cytotoxicity

Table 1. Number of crude extracts with cytotoxicity against human cell lines.

\begin{tabular}{|c|c|c|c|c|c|c|}
\hline \multirow{2}{*}{$\begin{array}{c}\text { Group of } \\
\text { gliding bacteria tested strain }\end{array}$} & \multirow{2}{*}{$\begin{array}{c}\text { Number of } \\
\text { active strain }\end{array}$} & \multicolumn{3}{|c|}{ Number of strains producing cytotoxic activities on } \\
\cline { 4 - 7 } & HeLa & HT-29 & KB & MCF-7 \\
\hline Group 1 & 2 & 0 & 0 & 0 & 0 & 0 \\
\hline Group 2 & 4 & 4 & 3 & 4 & 3 & 2 \\
\hline Group 3 & 2 & 0 & 0 & 0 & 0 & 0 \\
\hline Group 4 & 13 & 8 & 3 & 8 & 2 & 1 \\
\hline Group 5 & 3 & 0 & 0 & 0 & 0 & 0 \\
\hline Group 6 & 3 & 1 & 1 & 1 & 0 & 0 \\
\hline Total & 27 & 13 & 7 & 13 & 5 & 3 \\
\hline
\end{tabular}

biofilms, invertebrates and plant materials. These were collected in Thai sea water. All specimens, after rinsing with sterile seawater, were cut into small pieces $(0.5 \times 0.5$ $\mathrm{cm}$ ) with a sterilized sharp blade and placed on the isolation media in Petri dishes and incubated at room temperature. Swarm colony formation was observed under a stereomicroscope and a clean edge of swarm colony was cut into a small agar blocks by a sterilized sharp blade. These were transferred to a new cultivation plate containing modified SAP2 medium (tryptone, 1 g; yeast extract, 1 g; agar, $15 \mathrm{~g}$; sea water, 1 L) (Reichenbach, 1991) and incubated at room temperature. The subculturing was repeated until a pure culture could be obtained. For some isolates, the isolation of a single cell by a micromanipulator was performed in order to obtain a pure culture (Skerman, 1968; Sly and Arunpairojana, 1987).

\section{S rRNA gene sequences and phylogenetic analyse}

The genomic DNA of all isolates was extracted by a Wizard $^{\circledR}$ genomic DNA purification kit (Promega). The 16S rRNA genes were amplified by the polymerase chain reaction (PCR) technique, using universal primers BF1 (5'GAGTTTGATCATGGCTCAG-3') and BR1 (5'CGGTTACCTTGTTACGACTT-3'). The PCR products were purified by a GFX PCR DNA and gel band purification kit (Amersham). Sequencing reactions were performed with an ABI PRISM BigDye Terminator cycle sequencing ready-made kit (Applied Biosystem) (Srisukchayakul et al. 2007). The 16S rRNA gene sequences were edited and assembled with the BioEdit program (Hall, 1999). The nearly completed 16S rDNA sequences were compared with the sequences within the GenBank/EMBL/DDBJ databases using the BLAST search.
The alignment of the 16S rRNA gene sequences of the isolates and related genera were carried out by using the CLUSTAL X program ver 1.83 (Thompson et al. 1997). Nucleotide substitution rates ( $K_{\text {nuc }}$ values) (Kimura, 1980) were determined and a distance matrix tree was constructed by using the neighbor-joining method (Saitou and Nei, 1987). Alignment gaps and unidentified base positions were not taken into consideration in the calculations. The topology of the phylogenetic tree was evaluated by performing a bootstrap analysis with 1000 trials.

\section{Cultivation and crude extract preparation}

Ten milliliters of seed cultures (24 hrs) in SAP2 medium were transferred into 250-ml Erlenmeyer flasks containing $100 \mathrm{ml}$ of four different cultivation media including modified Vy/2 medium (baker's yeast paste, 5 g; seawater, 1 L) (Iizuka et al. 2003); modified RL 1 medium (peptone, 3 g; yeast extract, 2 g; $\mathrm{KNO}_{3}, 0.5$ g; vitamin $\mathrm{B}_{12}, 0.5 \mu \mathrm{g} / \mathrm{L}$; seawater, 1 L) (Spyere et al. 2003); modified CY medium (casitone, 10 g; malt extract, 2 g; yeast extract, 1 g; seawater, 1 L) (Suzuki et al. 1998) and SK medium (skim milk, 5 g; yeast extract, 3 g; $\mathrm{MgSO}_{4}, 1 \mathrm{~g}$; seawater, $1 \mathrm{~L}$ ). Each flask contained two grams of amberlite XAD-16 resins used for absorbing of secondary metabolites produced during the cultivation (Spyere et al. 2003). The cultivating flasks were incubated and shaken at $25^{\circ} \mathrm{C} ; 200$ rpm for 7 days. The amberlite XAD-16 resins were collected by filtering through a nylon mesh and washed with deionized water to remove salt and remaining cultivation media. The resins were set to dry at room temperature for $15 \mathrm{~min}$ and then soaked twice with $100 \mathrm{ml}$ of methanol for $30 \mathrm{~min}$. The methanol fractions were combined and evaporated to yield the dry crude extracts. 


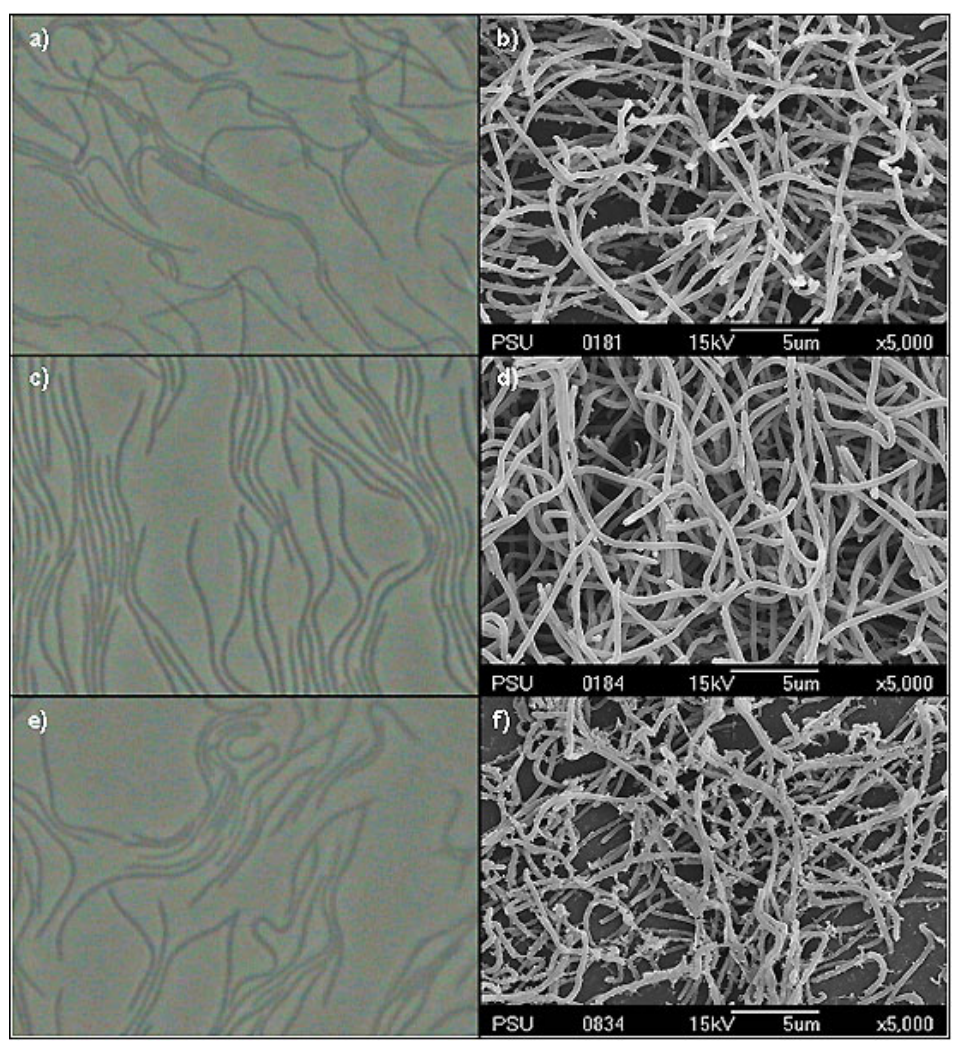

Figure 2. Cell morphology under a phase contrast and a scanning electron microscopes of TISTR1761 and TISTR1781. $\mathrm{a}-\mathrm{b})$ Phase contrast $(\mathrm{x} 100)$, bar $=10 \mu \mathrm{m}$, and scanning electron micrographs of TISTR1761 (AB433333), bar $=5 \mu \mathrm{m}$, cultivated on SAP2 agar.

C-d) Phase contrast (x100), bar $=10 \mu \mathrm{m}$, and scanning electron micrographs of TISTR1781 (AB443430), bar $=5 \mu \mathrm{m}$, cultivated on SAP2 agar.

e-f) Phase contrast $(x 100)$, bar $=10 \mu \mathrm{m}$, and scanning electron micrographs of TISTR1768 (AB444610), bar $=5 \mu \mathrm{m}$, cultivated on SAP2 agar.

\section{Cytotoxic assay}

Four different human cell lines including breast adenocarcinoma (MCF-7), colon cancer (HT-29), cervical cancer (HeLa) and oral cancer (KB) were used for the screening of cytotoxic activity using a sulphorodamine B (SRB) assay (Skehan et al. 1990). In brief, monolayer cultures of each cell line in 96-well microtiter plate $\left(2 \times 10^{3}\right.$ cells/well) were treated with marine gliding bacterial extracts dissolved in dimethyl sulfoxide (DMSO). The plate was incubated in a $\mathrm{CO}_{2}$ incubator at $37^{\circ} \mathrm{C}$ for 7 days. At the mid point of cultivation, the medium was refreshed once. The percentage of survival of the cancer cells was measured colorimetrically by SRB dye as described by Skehan et al. (1990). The absorbance was measured by a microplate reader at the wavelength of $492 \mathrm{~nm}$. One column of 96-well microtiter plate containing $2 \times 10^{3}$ cells/well of each cancer cell line was left untreated with a crude extract in order to use it as an internal control. Cytotoxicity was reported as the percentage of inhibition, calculated from the optical densities of treated wells and control, correlating to the viability of the cells as described in the equation below.
$\%$ inhibition $=\left[\left(\mathrm{OD}_{492}\right.\right.$ Control $-\mathrm{OD}_{492}$ Sample $) /\left(\mathrm{OD}_{492}\right.$ Control)] x 100

The growth inhibition about 80\% was used. [Eq. 1]

\section{Accession numbers}

The DDBJ/EMBL/GenBank accession numbers for the 16S rRNA gene sequences of strains TISTR1761, TISTR1763, TISTR1768, TISTR1780 and TISTR1781 are AB433333, AB433334, AB444610, AB433335 and AB443430, respectively.

\section{RESULTS AND DISCUSSION \\ Isolation, 16S rRNA gene and phylogenetic analyses}

In this study, eighty-four marine gliding bacterial isolates were obtained from different specimens collected in the Gulf of Thailand and the Andaman Sea. It was interesting to note that biofilms and macro-algae were among the most prolific sources of marine gliding bacteria (data not shown). Gliding bacteria are known to play important roles in the biodegradation of organic matter in seawaters such as the 
exopolysaccharides commonly present in the biofilm and algae (Johansen et al. 1999). Moreover, biofilm which is a consortium of microorganisms could also serve as nutritional sources for certain gliding bacteria with predatory behavior (Kadouri and O’Toole, 2005).

Initially all eighty four isolates were supposed to be screened for cytotoxicity using Glutamate $\left(\mathrm{NH}_{4} \mathrm{NO}_{3}, 0.01\right.$ g; $\mathrm{K}_{2} \mathrm{HPO}_{4} \cdot 3 \mathrm{H}_{2} \mathrm{O}, 0.01 \mathrm{~g}$; sodium glutamate, $1.0 \mathrm{~g}$; seawater, $1 \mathrm{~L})$ and Glycerol $\left(\mathrm{NH}_{4} \mathrm{NO}_{3}, 0.01 \mathrm{~g}\right.$; $\mathrm{K}_{2} \mathrm{HPO}_{4} \cdot 3 \mathrm{H}_{2} \mathrm{O}, 0.01 \mathrm{~g}$; glycerol, $1.0 \mathrm{~g}$; seawater, $1 \mathrm{~L}$ ) media for cultivation. However, the results showed that the crude extracts obtained from cultivation of forty nine isolates in these two media yielded no inhibitory activity against all four cancer cell lines which could be due to the compositions of the media. Therefore, Glutamate and Glycerol media were replaced with Vy/2, RL 1, CY and SK media for cultivation and only 27 isolates were selected for screening study based on their morphological characteristics.

Almost complete 16S rRNA gene sequences of the twentyseven selected strains and other neighboring species were used to construct the phylogenetic tree as shown in Figure 1. The results demonstrated that all marine gliding bacterial isolates belong to the Cytophaga-FlavobacteriumBacteroides (CFB) group and can be further divided into six different groups. Group 1 (TISTR1761 = AB433333 and TISTR1763 = AB433334) formed a distinct lineage separated from the closest neighbor, Flavobacteriaceae bacterium (DQ423479), with only $90.0 \%$ sequence similarity. It is decidedly possible to consider this group as a novel genus. Cell morphology of TISTR1761 is shown as long threads (Figure 2a and Figure 2b). However, more descriptive details such as $\mathrm{G}+\mathrm{C}$ mol content, biochemical and chemotaxonomic characteristics of this candidate novel genus are currently under investigation.

The 16S rRNA gene sequences (4 strains) and the phylogenetic analysis of group 2 confirmed that all members were identical to Tenacibaculum mesophilum, a marine gliding bacterium recently proposed by Suzuki et al. (2001). The 16S rRNA gene sequences of group 3 $($ TISTR1780 $=$ AB433335 and TISTR1781 $=$ AB443430) showed 98\% similarity with Fulvivirga kasyanovii (DQ836305) (Nedashkovskaya et al. 2007). The sequence similarity was low enough to hypothesize that this could potentially be a novel species of Fulvivirga.Group 4, which is the largest group, showed 16S rRNA gene sequence similarity close to Rapidithrix thailandica (AB284517), which was recently proposed by Srisukchayakul et al. (2007). However, the similarity between group 4 (TISTR1768 = AB444610) and Rapidithrix thailandica was only $98 \%$. It is, therefore, possible that they are different species of Rapidithrix, hence DNA-DNA hybridization is needed for confirmation. Groups 5 and 6 were identified as Aureispira marina (Hosoya et al. 2006) and Aureispira maritima (Hosoya et al. 2007) respectively. The 16S rRNA gene sequence similarities of groups 5 and 6 with A. marina and A. maritima were $99.0 \%$ and $99.0 \%$, respectively. Cell morphology of new species TISTR1781 and TISTR1768 are shown as long threads (Figure 2c and Figure 2f).

\section{Cytotoxicity screening}

The total of 108 crude extracts, obtained from the cultivation of each isolate in four different cultivation media, were submitted for cytotoxicity assay against four cancer cells lines including HeLa, HT-29, KB and MCF-7 using an SRB method. The results (Table 1) showed that 13 out of 27 isolates $(48.1 \%)$ could produce the crude extract which exhibited cytotoxicity, when tested the crude extract

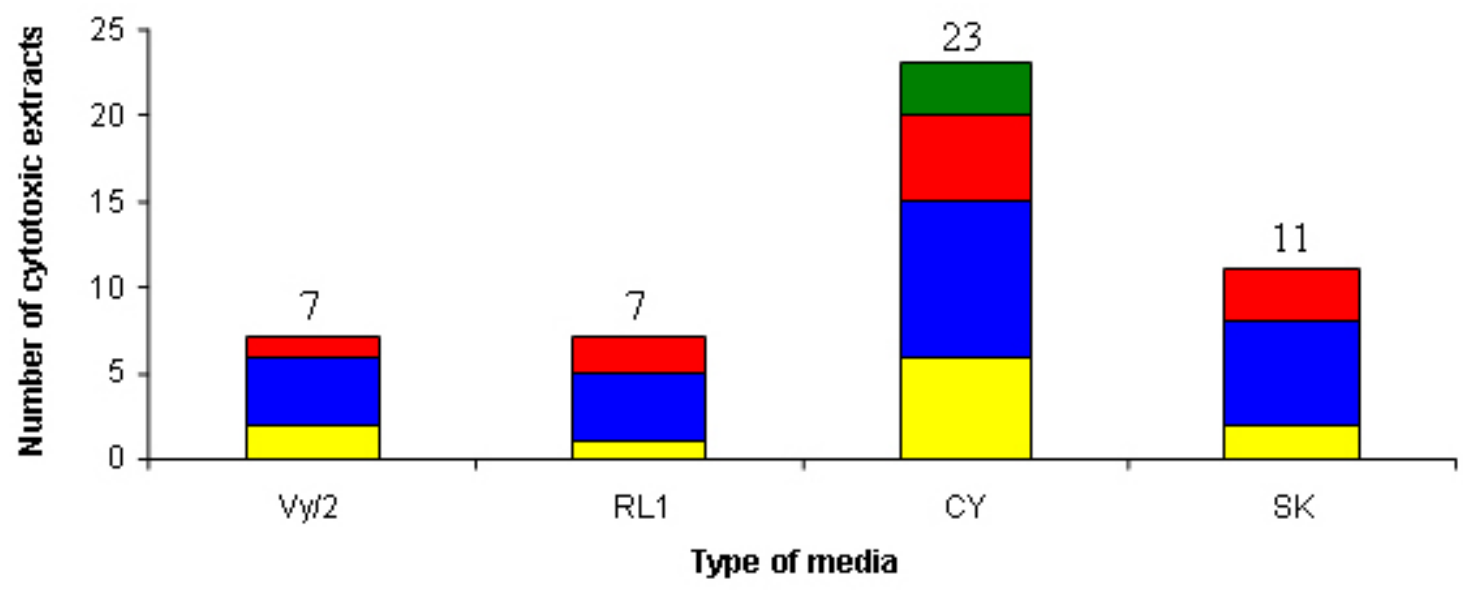

口HeLa $\square$ HT-29םKB $\square$ MCF-7

Figure 3. Effect of media on cytotoxicity. 
at a concentration of $25 \mu \mathrm{g} / \mathrm{ml}$ in SRB assay. Interestingly, the crude extracts obtained from group 2 (Tenacibaculum mesophilum) and group 4 (Rapidithrix thailandica) were capable of inhibiting all four cell lines whereas only one member of group 6 (Aureispira maritima) produced the crude extract which was active against HeLa and HT-29. There is only one strain of $R$. thailandica which could produce the extract with cytotoxicity against MCF-7. In contrast, the extracts of group 1 (the candidate novel genus), group 3 (Fulvivirga kasyanovii) and group 5 (Aureispira marina) exhibited no cytotoxicity. However, there has been no report on the secondary metabolite production by $T$. mesophilum and other gliding bacteria phylogenetically related to the strains obtained in this study. This suggests that marine gliding bacteria are still understudied and they could be as a potential source of cytotoxic compounds, especially the genera Tenacibaculum and Rapidithrix.

It is also important to note that the compositions of the cultivation media also played an important role in the production of the cytotoxic metabolites. From our observation, CY medium provided the faster growth of twenty-seven isolates than other cultivation media while $\mathrm{Vy} / 2$, RL 1 and SK media yield the same growth. As shown in Figure 3, CY medium yielded the highest number of crude extracts with cytotoxicity, followed by SK, RL 1 and $\mathrm{Vy} / 2$ media respectively. The CY medium was also the only medium which gave the crude extracts that could inhibit all four cell lines whereas other media could not yield the crude extract which inhibited MCF-7. This provided strong evidence that the media composition was one of the key factors for secondary metabolite production. Samarntarn et al. (1999) reported that amino acids and/or peptides in casitone, which was the key component in the CY medium, might serve as specific inducers for increasing the total alkaline protease production that causes the cytotoxic compound production.

This study is the first to report the isolation of novel marine gliding bacteria in Thailand and screening for cytotoxicity.

\section{ACKNOWLEDGEMENTS}

Asst. Prof. Dr. Supreeya Yuenyongsawasdi and Mr. Theerasak Anantapong for their assistances with the cytotoxic assay.

\section{REFERENCES}

BARBEYRON, Tristan; HARIDON, Stephane L.; CORRE, Erwan; KLOAREG, Bernard and POTIN, Philippe. Zobellia galactanovorans gen. nov., sp. nov., a marine species of Flavobacteriaceae isolated from a red alga, and classification of [Cytophaga] uliginosa (ZoBell and Upham 1944) Reichenbach 1989 as Zobellia uliginosa gen. nov., comb. nov. International Journal of Systematic and Evolutionary Microbiology, May 2001, vol. 51, no. 3, p. 985-997.
BOYD, Michael R.; FARINA, Carlo; BELFIORE, Pietro; GAGLIARDI, Stefania; KIM, Jin Woo; HAYAKAWA, Yoichi; BEUTLER, John A.; MCKEE, Tawnya C.; BOWMAN, Barry J. and BOWMAN, Emma Jean. Discovery of a novel antitumor benzolactone enamide class that selectively inhibits mammalian vacuolar-type $\left(\mathrm{H}^{+}\right)$ATPases. The Journal of Pharmacology and Experimental Therapeutics, April 2001, vol. 297, no. 1, p. 114-120.

CURIEL, Rafael E.; GARCIA, Carmen S.; FAROOQ, Lubna; AGUERO, Martin F. and ESPINOZA-DELGADO, Igor. Bryostatin-1 and IL-2 synergize to induce IFN-gamma expression in human peripheral blood $\mathrm{T}$ cells: implications for cancer immunotherapy. The Journal of Immunology, November 2001, vol. 167, no. 9, p. 4828-4837.

FELING, Robert H.; BUCHANAN, Greg O.; MINCER, Tracy J.; KAUFFMAN, Christopher A.; JENSEN, Paul R. and FENICAL, William. Salinosporamide A: a highly cytotoxic proteasome inhibitor from a novel microbial source, a marine bacterium of the new genus Salinospora. Angewandte Chemie International Edition, January 2003, vol. 42, no. 3, p. 355-357.

FUDOU, Ryosuke; IIZUKA, Takashi and YAMANAKA, Shigeru. Haliangicin, a novel antifungal metabolite produced by a marine myxobacterium: 1 . Fermentation and biological characteristics. The Journal of Antibiotics, February 2001, vol. 54, no. 2, p. 149-152.

GARO, Eliane; STARKS, Courtney M.; JENSEN, Paul R.; FENICAL, William; LOBKOVSKY, Emil and CLARDY, Jon. Trichodermamides A and B, cytotoxic modified dipeptides from the marine-derived fungus Trichoderma virens. Journal of Natural Products, March 2003, vol. 66, no. 3, p. 423-426.

GORAJANA, A.; VENKATESAN, M.; VINJAMURI, S.; KURADA, B.V.V.S.N.; PEELA, S.; JANGAM, P.; POLURI, E. and ZEECK, A. Resistoflavine, cytotoxic compound from a marine actinomycete, Streptomyces chibaensis $\mathrm{AUBN}_{1} / 7$. Microbiological Research, September 2007, vol. 162, no. 4, p. 322-327.

HALL, Tom A. BioEdit: a user-friendly biological sequence alignment editor and analysis program for Windows 95/98/NT. Nucleic Acids Symposium Series, 1999, vol. 41, p. 765-768.

HOSOYA, Shoichi; ARUNPAIROJANA, Vullapa; SUWANNACHART, Chatrudee; KANJANA-OPAS, Akkharawit and YOKOTA, Akira. Aureispira marina gen. nov., sp. nov., a gliding, arachidonic acid-containing bacterium isolated from the southern coastline of Thailand. International Journal of Systematic and Evolutionary Microbiology, December 2006, vol. 56, no. 12, p. 29312935.

HOSOYA, Shoichi; ARUNPAIROJANA, Vullapa; SUWANNACHART, Chatrudee; KANJANA-OPAS, 
Akkharawit and YOKOTA, Akira. Aureispira maritima sp. nov., isolated from marine barnacle debris. International Journal of Systematic and Evolutionary Microbiology, September 2007, vol. 57, no. 9, p. 1948-1951.

HUTSON, Thomas E.; GANAPATHI, Ram; ELSON, Paul; MEKHAIL, Tarek; OLENCKI, Thomas; BUDD, Thomas G. and BUKOWSKI, Ronald M. Phase I trial of vinorelbine and diphenylhydantoin in patients with refractory carcinoma. Investigational New Drugs, August 2004, vol. 22, no. 3, p. 277-284.

IIZUKA, Takashi; JOJIMA, Yasuko; FUDOU, Ryosuke; HIRAISHI, Akira; AHN, Jong-Woong and YAMANAKA, Shigeru. Plesiocystis pacifica gen. nov., sp. nov., a marine myxobacterium that contains dihydrogenated menaquinone, isolated from the Pacific coasts of Japan. International Journal of Systematic and Evolutionary Microbiology, January 2003, vol. 53, no. 1, p. 189-195.

IIZUKA, Takashi; FUDOU, Ryosuke; JOJIMA, Yasuko; OGAWA, Sumie; YAMANAKA, Shigeru; INUKAI, Yasutaka and OJIKA, Makoto. Miuraenamides A and B, novel antimicrobial cyclic depsipeptides from a new slightly halophilic myxobacterium: taxonomy, production, and biological properties. The Journal of Antibiotics, August 2006, vol. 59, no. 7, p. 385-391.

IZBICKA, E.; LAWRENCE, R.; RAYMOND, E.; ECKHARDT, G.; FAIRCLOTH, G.; JIMENO, J.; CLARK, G. and VONHOFF, D.D. In vitro antitumor activity of the novel marine agent, Ecteinascidin-743 (ET-743, NSC648766) against human tumors explanted from patients. Annals of Oncology, September 1998, vol. 9, no. 9, p. 981987.

JOHANSEN, Jens E.; NIELSEN, Preben and SJOHOLM, Carsten. Description of Cellulophaga baltica gen. nov., sp. nov. and Cellulophaga fucicola gen. nov., sp. nov. and reclassification of Cytophaga lytica to Cellulophaga lytica gen. nov., comb. nov. International Journal of Systematic and Evolutionary Microbiology, July 1999, vol. 49, no. 3, p. 1231-1240.

KANJANA-OPAS, Akkharawit; PANPHON, Somrak; FUN, Hoong-Kun and CHANTRAPROMMA, Suchada. 4Methyl-3H-pyrrolo[2,3-c]quinoline. Acta Crystallographica - Section E, October 2006, vol. 62, no. 7, p. 2728-2730.

KADOURI, Daniel and O'TOOLE, George A. Susceptibility of biofilms to Bdellovibrio bacteriovorus attack. Applied and Environmental Microbiology, July 2005, vol. 71, no. 7, p. 4044-4051.

KIMURA, Motoo. A simple method for estimating evolutionary rates of base substitutions through comparative studies of nucleotide sequences. Journal of Molecular Evolution, June 1980, vol. 16, no. 2, p. 111-120.
MIOT-NOIRAULT, Elisabeth; LEGAULT, Jean; CACHIN, Florent; MOUNETOU, Emmanuelle; DEGOUL, Francoise; GAUDREAULT, Rene C.; MOINS, Nicole and MADELMONT, Jean C. Antineoplastic potency of arylchloroethylurea derivatives in murine colon carcinoma. Investigational New Drugs, November 2004, vol. 22, no. 4, p. 369-378.

NAKAGAWA, Yasuyoshi; SUZUKI, Makoto and HATANO, Kazunori. Phylogenetic diversity of Cytophagalike strains isolated from the sub-tropical zone of Japan. The Institute for Fermentation, Osaka Research Communications, March 2001, no. 20, p. 61-71.

NEDASHKOVSKAYA, Olga I.; KIM, Seung Bum; SHIN, Dong Sung; BELENEVA, Irina A. and MIKHAILOV, Valery V. Fulvivirga kasyanovii gen. nov., sp. nov., a novel member of the phylum Bacteroidetes isolated from seawater in a mussel farm. International Journal of Systematic and Evolutionary Microbiology, May 2007, vol. 57, no. 5, p. 1046-1049.

REICHENBACH, H. The Order Cytophagales. In: STARR, M.P.; STOLP, H.; TRIIPER, H.G.; BALOWS, A. and SCHLEGEL, H.G. eds, The Prokaryotes. $2^{\text {nd }}$ ed. Berlin, Springer Verlag, 1991, vol. 4, p. 3631-3675.

SAITOU, Naruya and NEI, Masatoshi. The neighborjoining method: a new method for reconstructing phylogenetic trees. Molecular Biology and Evolution, July 1987, vol. 4, no. 4, p. 406-425.

SAMARNTARN, Warin; CHEEVADHANARAK, Supaporn and TANTICHAROEN, Morakot. Production of alkaline protease by a genetically engineered Aspergillus oryzae U1521. The Journal of General and Applied Microbiology, 1999, vol. 45, no. 3, p. 99-103.

SCHILDER, Russell J.; BLESSING, John A.; PEARL, Michael L. and ROSE, Peter G. Evaluation of irofulven (MGI-114) in the treatment of recurrent or persistent endometrial carcinoma: A phase II study of the Gynecologic Oncology Group. Investigational New Drugs, August 2004, vol. 22, no. 3, p. 343-349.

SKEHAN, Philip; STORENG, Ritsa; SCUDIERO, Dominic; MONKS, Anne; MCMAHON, James; VISTICA, David; WARREN, Jonathan T; BOKESCH, Heidi; KENNEY, Susan and BOYD, Michael R. New colorimetric cytotoxicity assay for anticancer-drug screening. Journal of the National Cancer Institute, July 1990, vol. 82, no. 13, p. 1107-1112.

SKERMAN, V.B. A new type of micromanipulator and microforge. Journal of General Microbiology, December 1968, vol. 54, no. 2, p. 287-297.

SLY, L.I. and ARUNPAIROJANA, V. Isolation of manganese-oxidizing Pedomicrobium cultures from water 
by micromanipulation. Journal of Microbiological Methods, March 1987, vol. 6, no. 3, p. 177-182.

SRISUKCHAYAKUL, Pornpoj; SUWANNACHART, Chatrudee; SANGNOI, Yutthapong; KANJANA-OPAS, Akkharawit; HOSOYA, Shoichi; YOKOTA, Akira and ARUNPAIROJANA, Vullapa. Rapidithrix thailandica gen. nov., sp. nov., a marine gliding bacterium isolated from samples collected from the Andaman sea, along the southern coastline of Thailand. International Journal of Systematic and Evolutionary Microbiology, October 2007, vol. 57, no. 10, p. 2275-2279.

SUZUKI, Yoshihiro; OJIKA, Makoto; SAKAGAMI, Youji; FUDOU, Ryosuke and YAMANAKA, Shigeru. Cystothiazoles C-F, new bithiazole-type antibiotics from the myxobacterium Cystobacter fuscus. Tetrahedron, September 1998, vol. 54, no. 38, p. 11399-11404.

SUZUKI, Makoto; NAKAGAWA, Yasuyoshi; HARAYAMA, Shigeaki and YAMAMOTO, Satoshi. Phylogenetic analysis and taxonomic study of marine Cytophaga-like bacteria: proposal for Tenacibaculum gen. nov. with Tenacibaculum maritimum comb. nov. and Tenacibaculum ovolyticum comb. nov., and description of Tenacibaculum mesophilum sp. nov. and Tenacibaculum amylolyticum sp. nov. International Journal of Systematic and Evolutionary Microbiology, September 2001, vol. 51, no. 5, p. 1639-1652.

THOMPSON, Julie D.; GIBSON, Toby J.; PLEWNIAK, Frederic; JEANMOUGIN, Francois and HIGGINS, Desmond G. The CLUSTAL X windows interface: flexible strategies for multiple sequence alignment aided by quality analysis tools. Nucleic Acids Research, December 1997, vol. 25, no. 24, p. 4876-4882.

WILLIAMS, Philip G.; YOSHIDA, Wesley Y.; QUON, Michael K.; MOORE, Richard E. and PAUL, Valerie J. The structure of palau'amide, a potent cytotoxin from a species of the marine cyanobacterium Lyngbya. Journal of Natural Products, December 2003, vol. 66, no. 12, p. 15451549.

WILLIAMS, Philip G.; YOSHIDA, Wesley Y.; MOORE, Richard E. and PAUL, Valerie J. Micromide and guamamide: cytotoxic alkaloids from a species of the marine cyanobacterium Symploca. Journal of Natural Products, January 2004, vol. 67, no. 1, p. 49-53. 